\title{
SYSTEM REVIEW ON DISTRIBUTION OF MULTIPLE MICRONUTRIENT POWDER PROGRAM IN PRAYA TENGAH, CENTRAL LOMBOK DISTRICT
}

\author{
Muharni \\ Dosen Poltekkes Kemenkes Riau Jurusan Gizi
}

\begin{abstract}
Objective

To review the implementation of existing distribution system of Multiple Micronutrient Powder (MNP) program in relation to coverage in Praya Tengah, Central Lombok District.

Design

Health System Analysis (HSA) was used to review each essential component of MNP distribution. Methods were in-depth interview health care provider of MNP program, document review, observation and interviewing cadre and mother/caregiver with targeted children (12-59 months old children).
\end{abstract}

Setting

Praya Tengah sub-district, Central Lombok District, Indonesia.

Subjects

A total of 240 randomly selected underfive children (12-59 months old), 48 cadres responsible for MNP program, 2 nutrition staff responsible for MNP program and 1 head of health center, one nutrition staff at district health office (DHO) and head of DHO also a representative person of UNICEF.

Results

There was no mechanism of requesting system from Posyandu to District Health Office (DHO). Score of resources in Posyandu was 50\%, with no records of MNP logistic and only half Posyandu had minimally two trained cadres. Posyandu as main site of MNP distribution was accessible by mostly cadre (95.8\%) and mother/caregiver (78.3\%). Average score of planning and management in Puskesmas was $50 \%$ and lack of effective supervision. Training for cadres only conducted two times since the last three years yielding poor knowledge of trained cadre. Only 30.2\% cadre ever trained on MNP program. About $79.2 \%$ Posyandu submitted last report of MNP distribution on Posyandu. Most of Posyandu (85.4\%) had experienced of over stocking MNP and mostly due to over dropping from Puskesmas. Community participation on MNP distribution especially community leader was not sufficient. The coverage of MNP distribution in the last six months was only $37.9 \%$.

\section{Conclusions}

Almost all of essential components of MNP distribution system were mostly deficient. Since all of them were influenced to each other, any deficiency might give effect to others; hence, coverage of MNP distribution was low.

Keywords: multiple micronutrient powder, health system review, distribution

\section{INTRODUCTION}

Anemia is the most common nutrient deficiency affecting both developing and developed countries, especially among pregnant women and young children. The National Health and Households Survey (2001) confirmed that anemia was still the main problem in Indonesia with increasing prevalence (>55\%), particularly among children less than 24 months.

A new method has been introduced to the world as an alternative to help reduce prevalence of anemia. 
Micronutrients powder (MNP), a home fortification contains of vitamins and minerals in a form of powder, was introduced in $1996 . \quad$ Randomized community-based studies on MNP involving both anemic and non-anemic children have been completed in diverse setting i.e. Ghana [1-2], Cambodia [3], Pakistan [4], Bangladesh [5], India [6] and Haiti [7].

Many Asian countries were poised to scale up the use of MNP as part of an integrated infant young child nutrition strategy including Indonesia [8]. Before scaling-up the MNP program nationally, one of the requirements of establishing effective and efficient scale-up program is to define the proper delivery strategy or distribution system, hence high and equitable coverage of program will be obtained and maintained [9].

Community Health Systems Strengthening (CHANSYS) program, a collaboration project between UNICEF and District Health Office of Central Lombok has been running since 2007 [10]. The ongoing program in Central Lombok District uses MNP as part of a program package to improve child health. The MNP are distributed to all of the children aged 6-59 months in CHANSYS area. Posyandu, as a fixed site of distribution, has been used as distribution channel of MNP, and community outreach, known as sweeping activity. Mothers/caregivers are given fifteen sachets of MNP monthly, to be given to their children flexibly by sprinkled onto foods prepared in the home but not more than one sachet daily.

By reviewing the existing distribution system of MNP program in CHANSYS area, more information regarding distribution system in relation to coverage will be obtained hence this study will give insight to the CHANSYS's program planner, implementer and coordinator in their efforts to construct a proper guideline of MNP distribution.

This study aimed to review the implementation of existing distribution system of MNP program in relation to coverage in Praya Tengah, Central Lombok District.

\section{METHODS \\ Study design and site}

This cross sectional study was conducted in all villages (10) of Praya Tengah sub-district from February to March 2010. The study was conducted in one among four sub-district of CHANSYS area in Central Lombok. The selection criteria of this sub-district are the nearest distance from central district to subdistrict, less population density, small area of sub-district, highest number of Posyandu Mandiri, smallest number of underfive children per Posyandu.

\section{Subjects}

There were two Puskesmas existed in Praya Tengah sub-district. About 48 Posyandu were randomly selected out of 93 Posyandu under supervision the two Puskesmas. In this study, cadre coordinator of each Posyandu, nutrition staff at Puskesmas responsible for MNP program, head of Puskesmas, head of nutrition section at DHO, head of DHO and UNICEF's representative person responsible for MNP program.

To determine the coverage of MNP distribution in this area, a sample size of 240 underfive children (12-59 months old) was needed considering design effect and $10 \%$ non-response cases [11]. The underfive children was randomly selected using one stage cluster sampling procedure; 48 clusters of Posyandu were selected randomly. The targeted children obtained from free population by mapping the area of Posyandu into four quadrants. On each quadrant including the center area, one child was selected without randomization. Hence, five children aged 12-59 were obtained per Posyandu. Coverage of MNP was measured as proportion of children aged 6-59 months who receive 60 sachets of MNP in the last six months by interviewing mother/caregiver. 


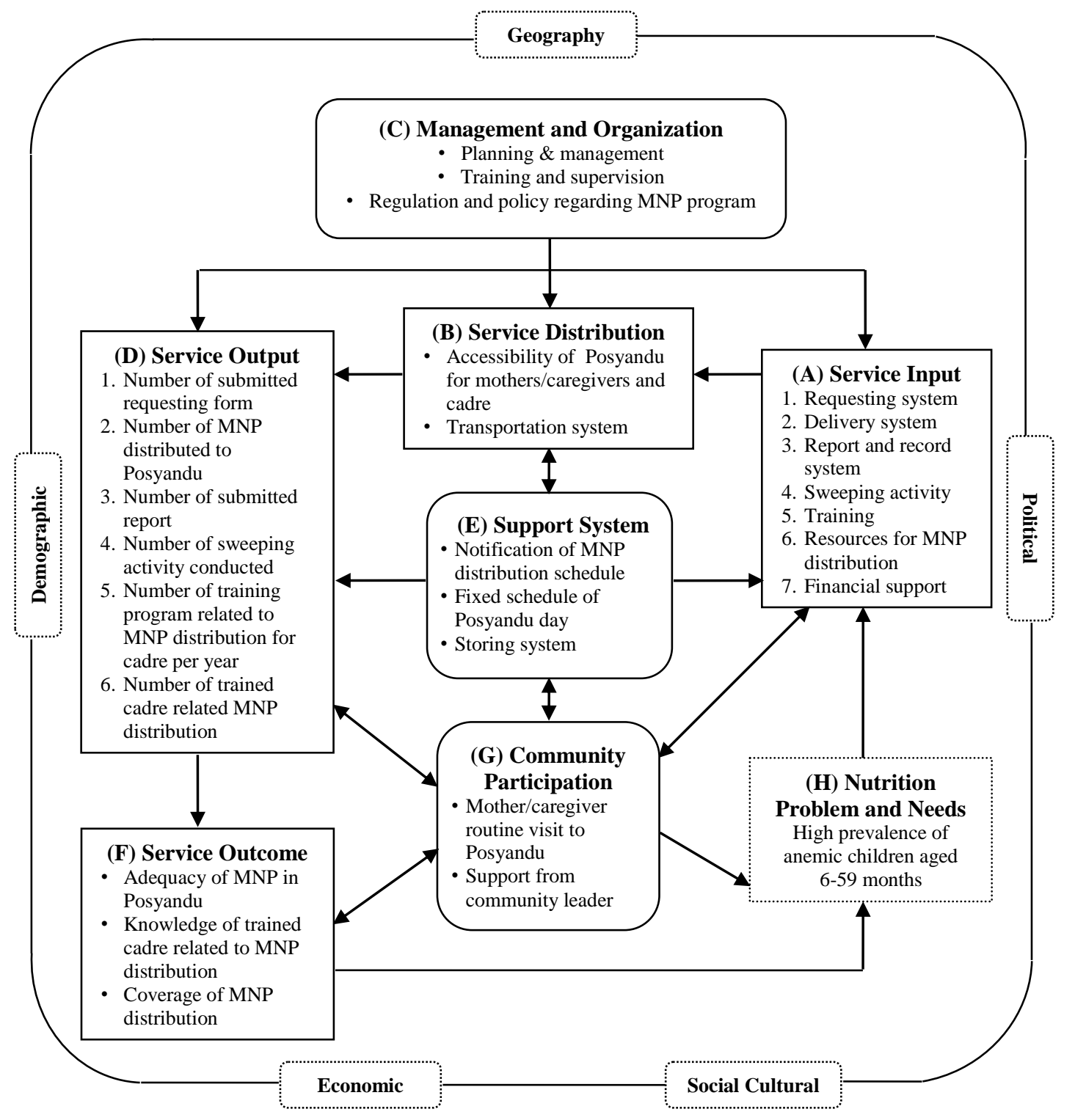

Figure 1. Distribution system of MNP program

\section{Methods of assessment}

Health System Analysis (HSA) was used as management of tools to review the existing MNP distribution system. If one of the essential components is lacking, the whole system will not function properly since each components are interrelated to another. Figure 1 shows MNP distribution as a health system with its essential components.

Data collection was using several methods including interview using structured questionnaire, in-depth interview, observation using check list questionnaire and record checking/document review (secondary data review). The interview with mother and cadre conducted by local trained interviewers, personally and in convenient situation (inside or outside the house) for each selected subject. The questionnaires were pre-tested prior the actual data collection. Observation on storage was conducted by one observer to avoid interpersonal bias. The in-depth interview and secondary data obtained from responsible person of MNP program from district health office, Puskesmas and Posyandu.

\section{Data analysis}

After data collection, all of data were cleaning. All variables obtained from interview using structured questionnaires 
were analyzed using descriptive statistic by SPSS version 16.0. Data on in-depth interview and observation were summarized based on defined theme and then descriptively analyzed.

\section{Ethical consideration}

The protocol of the study obtained an ethical clearance from the Ethical Committee of the Medical Faculty, University of Indonesia. Permission to conduct the study was obtained from the local government offices. The interviewers gave explanation on the research purpose, procedure and ensure confidentiality to all respondents. All of data collection was obtained with the least burden on the respondent's side. The respondents had the rights to refuse or quit at any time. Before conducting interview, the respondents signed a written consent.

\section{RESULTS}

\section{Baseline characteristics}

Praya Tengah sub-district had two Puskesmas namely Batunyala and Pengadang. Table 1 will show characteristics of those Puskesmas under study. The peripheral health facilities studied included two Puskesmas covering 104 Posyandu, 5 Pustu and 7 Polindes. There were 5 nutrition staffs from the two Puskesmas responsible for nutrition program giving ratio to inhabitants at 7.7 per 100.000 and ratio to underfive children at $1: 1573$.

Most caregivers (93.8\%) of underfive children were their mothers. Others caregivers were grandmother, aunty, father and foster mother. Median age of the caregivers was 29 (ranged from 17 to 50 years). Most of the father and mother $(26.3 \%$ and $34.6 \%$ respectively) had educational level on elementary school graduate. The main occupation of father was laborer (24.3\%) and others occupation of father were private employee, mechanic and craftsmen. Most of mother was housewife $(43.8 \%)$ and others occupation of mother were craftsmen and private employee (Table 2).

Most cadres were women (95.8\%), graduated from senior high school $(41.7 \%)$ while $39.6 \%$ cadres were housewife and others occupation were district honorer, entrepreneur, driver and craftsmen. Most cadres on Posyandu (88.9\%) were active. More than half of cadres $(60.4 \%)$ had being cadre for $\geq 10$ years (ranged from 1 to 29 years).

\section{Essential components of MNP distribution system}

Complete essential components shows on Figure 1.

Table 1. Characteristics of Puskesmas under study in Praya Tengah sub-district

\begin{tabular}{lccc}
\hline \multicolumn{1}{c}{ Characteristic } & Batunyala & Pengadang & Total \\
\hline \hline Number of village under supervision & 5 & 5 & 10 \\
Number of Posyandu under supervision & 54 & 50 & 104 \\
Total population & 31,686 & 33,169 & 64,855 \\
Number of cadre & 109 & 126 & 235 \\
Number of active cadre, $n(\%)$ & $95(87)$ & $114(91)$ & $209(89)$ \\
Number of trained cadre, $n(\%)$ & $35(32)$ & $36(29)$ & $71(30)$ \\
Number of underfive children & 3359 & 4504 & 7863 \\
Ratio Posyandu : underfive children & $1: 62$ & $1: 90$ & $1: 75$ \\
\hline
\end{tabular}

\section{a. Service input}

Initially, MNP would be distributed every six months concurrently with vitamin A distribution. However, in the study area, the practice was that mothers/caregivers only visited Posyandu if their children would get something in addition to routine weighing. This practice particularly occured with children above 12 months, who had completed immunization. Therefore, the Puskesmas staff and cadre decided to distribute MNP monthly during Posyandu activity. They asked mother to return empty sachets of MNP before 
getting new one, aiming to increase children's attendance on Posyandu day. However, it only happened for the first four months. Afterwards, due to direction by DHO in order to achieve high coverage of MNP, they distributed MNP bimonthly as one box of MNP consisted of 30 sachets, sufficient for two months supply. During the last distribution in August 2009, 60 MNP sachets were distributed for four months, to similar vitamin $\mathrm{A}$ distribution months of February and August, as the highest Posyandu attendance.

There was no requesting system from cadre to Puskesmas staff available and also from Puskesmas staff to DHO. Requesting system only occurred from DHO to UNICEF. Based on in-depth interview to nutrition staff at DHO, DHO determined targeted children (6-59 months old) based on report of Puskesmas on growth monitoring program and sometimes using projection data. The last request for delivery in August 2009 was made more than one year in advance (June 2008).

MNP distribution was attached to monthly growth monitoring program in Posyandu. The MNP stock was delivered to Posyandu on the day of distribution by Puskesmas staff. There were no record of logistic available at Posyandu, Puskesmas and nor DHO. Although 83.3\% cadres conducting sweeping activity, however, there were no records available as well.

There was only two times cadre's training for MNP: in 2007 and 2009. Every Puskesmas organized half day training to five villages, using lecture and practice, but no evaluation. UNICEF provided financial support for procurement of MNP, communication material, training for nutrition staff and cadre, socialization and supervision, however, no operational financial support to distribute MNP

Despite both Puskesmas had all their nutrition staff trained, only $50 \%$ of Posyandu had minimally two trained cadre on MNP but 6 Posyandu (12.5\%) had none trained cadre. Since there was no requesting mechanism from Puskesmas staff to DHO, obviously there was no record of MNP request nor record of MNP delivery to Posyandu and MNP logistic in both Puskesmas. The last supply of MNP to Puskesmas was delivered in August 2009 which also had to be delivered in the same month to Posyandu.

\section{b. Service distribution}

Most mother/caregiver (78.3\%) had good accessibility to reach Posyandu and only small proportion had less accessibility to Posyandu. Walking distance to Posyandu ranged between 1-60 minutes. Most mother/caregiver went to Posyandu by foot $(91.67 \%)$ and only $8.3 \%$ of mother/caregiver utilized different vehicles to reach Posyandu: $85 \%$ by motorcycle, $10 \%$ by angkot and $5 \%$ by cidomo. The cost every visit to Posyandu ranged between IDR 0-2000.

Almost all cadres could reach Posyandu easily. Walking distance to Posyandu ranged between 0-20 minutes. About $85.4 \%$ cadre walked to Posyandu and $14.6 \%$ utilized motorcycle to reach Posyandu. The cost of every visit to Posyandu ranged between IDR 0-2000. Cost for cadre to reach Puskesmas was ranged between IDR 2000-15000.

\section{c. Management and organization}

Based on in-depth interview to nutrition staff and head of Puskesmas, MNP program was a top down program and no local planning ever made at Puskesmas level. It was attached to nutrition section program, therefore nutrition staff responsible for MNP distribution and no specific job description and areas of responsibility were determined. Meetings to discuss schedule and problem were held irregularly. Puskesmas obliged to every planned activities made by DHO. Puskesmas only determined schedule of MNP distribution which attached to monthly Posyandu day. Average score for planning and management at Puskesmas was 50\%.

Head of DHO explained that there were no specific regulation and policy ever made 
since the initiation of the program. This program was attached to nutrition section program. MNP distribution was using Posyandu as channel of delivery and supervision also attached to growth monitoring program. Based on in-depth interview with UNICEF responsible person, this program was intended to advocating local government to use MNP as part of infant young child feeding practices using the local existing health system delivery and to avoiding dependency.

Table 2. Characteristic of socio-economic status of household in Praya Tengah sub-district

\begin{tabular}{|c|c|}
\hline Characteristic & Total \\
\hline Family size ${ }^{1}$, median (min,max) & $4(2,10)$ \\
\hline \multicolumn{2}{|l|}{ Underfive children in the household ${ }^{1}, n(\%)$} \\
\hline 1 underfive & $216(90)$ \\
\hline$>1$ underfive & $24(10)$ \\
\hline \multicolumn{2}{|l|}{ Father educational level ${ }^{2}, n(\%)$} \\
\hline Never or $<3$ years of schooling & $39(16.5)$ \\
\hline Elementary school & $62(26.3)$ \\
\hline Junior high school & $56(23.7)$ \\
\hline Senior high school & $59(25)$ \\
\hline University & $20(8.5)$ \\
\hline \multicolumn{2}{|l|}{ Mother educational level ${ }^{1}, n(\%)$} \\
\hline Never or $<3$ years of schooling & $24(10)$ \\
\hline Elementary school & 83 (34.6) \\
\hline Junior high school & $59(24.6)$ \\
\hline Senior high school & $62(25.8)$ \\
\hline University & $12(5)$ \\
\hline \multicolumn{2}{|l|}{ Father's occupation ${ }^{3}, n(\%)$} \\
\hline Farmer/fisherman/breeder (land/boat/husbandry owner) & $50(21.5)$ \\
\hline Farmer/fisherman (not land/boat husbandry owner) & $28(12)$ \\
\hline Government employee & $24(10.3)$ \\
\hline Entrepreneur & $10(4.3)$ \\
\hline Laborer & $58(24.8)$ \\
\hline Migrant worker & $40(17.1)$ \\
\hline Unemployed & $3(1.3)$ \\
\hline Driver/ojek/cidomo & $11(4.7)$ \\
\hline Others & $10(4.3)$ \\
\hline \multicolumn{2}{|l|}{ Mother's occupation $^{1}, n(\%)$} \\
\hline Housewife & $105(43.8)$ \\
\hline Farmer/fisherman/breeder (land/boat/husbandry owner) & $39(16.2)$ \\
\hline Farmer/fisherman (not land/boat husbandry owner) & $23(9.6)$ \\
\hline Government employee & $18(7.5)$ \\
\hline Entrepreneur & $16(6.7)$ \\
\hline Laborer & $22(9.1)$ \\
\hline Migrant worker & $8(3.3)$ \\
\hline Others & $9(3.7)$ \\
\hline
\end{tabular}

\section{d. Service output}

Since there was no mechanism of requesting system from Posyandu to Puskesmas and also to DHO, there were no requesting reports available ever. Due to poor record system on MNP distribution, number of MNP distributed to Posyandu was not available. Puskesmas staff just brought some boxes of MNP on the day of delivery to Posyandu.

About $79.2 \%$ of Posyandu submitted report of last MNP distribution on August 2009. Most reports were made by cadre but some of them were made by Puskesmas staff. Only 11 children were actually given MNP at home (sweeping 
activity) among 231 eligible children, with a ratio of 1:21 (one had been swept among 21 underfive children)

Since initiation of the program, two training for cadre on MNP were conducted. First training conducted in 2007 and the last one was in 2009, with only two cadres from eachPosyandu attended. During the first training, $83.3 \%$ of cadre's coordinator attended the training and only $56.3 \%$ of them attended the second one. About $87.5 \%$ of Posyandu had at least one trained cadre and $54.2 \%$ of Posyandu had their cadre coordinator attended both training. About half of the Posyandu (50\%) had minimally two trained cadre at least attended one training on MNP program. Only $30.2 \%$ cadre ever trained on MNP program.

\section{e. Support system}

Almost all mother/caregiver acknowledged MNP distribution. The channel of information received mostly from announcement by mosque. About 83.3\% Posyandu had fixed schedule of monthly Posyandu day. There were no specific place to store MNP stock at Posyandu and Puskesma. There were 24 (50\%) Posyandu had poor storing system. In both Puskesmas, there were left over stock that had not been distributed yet.

\section{f. Service outcome}

Most Posyandu (85.4\%) had experienced over stocking of MNP and only one Posyandu ever experience lack of MNP stock on the day of MNP distribution. The main reason of over stocking was overload dropping from Puskesmas (70.7\%), mother didn't want to take MNP (19.5\%) and mother didn't come to Posyandu (9.8\%). The reason for lack of MNP stock was due to lack of dropping from Puskesmas. In the last six months the distribution of MNP only occurred in August 2009. The children were given 60 sachets for 4 months. During the last two months (December 2009 - January 2010), MNP was only given for mother/caregiver who asked for it (Table 3).

Table 3. Distribution of MNP coverage in the last 6 months in Praya Tengah sub-district

\begin{tabular}{lc}
\hline \multicolumn{1}{c}{ MNP received in the last 6 months } & Total \\
\hline \hline MNP received in the last 6 months $^{1}, n(\%)$ & $25(10.8)$ \\
0 & $\mathbf{9 8}(\mathbf{4 2 . 2})$ \\
$<60$ sachets & $88(37.9)$ \\
60 sachets & $21(8.9)$ \\
$>60$ sachets & $91(39.2)$ \\
MNP received on August $2009^{1}, n(\%)$ & $\mathbf{9 2}(\mathbf{3 9 . 6})$ \\
0 & $4720.3)$ \\
$<60$ sachets & $2(0.8)$ \\
60 sachets & \\
$>60$ sachets & $\mathbf{9 5}(\mathbf{4 1 . 1})$ \\
Main reason for irregular received of MNP ${ }^{2}, n(\%)$ & $85(36.8)$ \\
Child dislike MNP & $15(6.5)$ \\
No stock available at Posyandu & $8(3.5)$ \\
Irregular visit to Posyandu & $6(2.6)$ \\
Posyandu too far away & $21(9)$ \\
Mother disliked MNP to be given to her child &
\end{tabular}

\section{g. Community participation}

About $77.1 \%$ of mother/caregiver visited Posyandu $\geq 4$ times in the last six months. Reason for never or less visiting to Posyandu was displayed in Table 4.10; due to busy working (29.1\%) and others reason were went out of the village on the day of distribution, sickness and children were afraid to the weighing activity. Almost half of head of sub-village (47.9\%) supported MNP distribution by giving information of MNP distribution schedule 
monthly. Others support were providing place for MNP distribution and attending MNP distribution.

\section{DISCUSSION}

There were several efficacy studies on MNP had been conducted on different areas in Indonesia such as in urban slums Jakarta, rural Sukabumi [12] and North Jakarta [13]. Findings in those studies showed a consistent result of improving anemia prevalence on underfive children after giving MNP for several months. However, we still need to evaluate MNP program in a community setting; hence, a public health effectiveness of MNP program is needed. To date, this is the first study evaluating public health effectiveness of MNP program in a community setting.

MNP program was part of CHANSYS project which consist of several intervention package of improving health of underfive children and strengthening service delivery system. Since there were limited study regarding MNP distribution program, this study would only focused on MNP distribution by reviewing essential system component of distribution of MNP program.

This study took underfive children as sample based on quadrants without random selection among available underfive children in each quadrant. It means that those samples probably may not represent the area. When we compare some characteristics of mother/caregiver between CHANSYS baseline survey [14] and this study: mean of mother's age was 27 years vs. 29 years, mother's education of illiteracy and elementary school graduate was $56 \%$ vs. $44.6 \%$, mother's as housewife was $76 \%$ vs. $43.8 \%$, and Posyandu's routine visit was $62 \%$ vs. $77 \%$. Besides mother's occupation as housewife, others important characteristics were quite comparable, considering that this study purposively selected the best practice of MNP program in Lombok Tengah.
MNP was distributed free of charge to all children age 6-59 months old. The choice of distribution strategy was utilizing Posyandu as already established at every sub-village. This choice was in line with the intention of the project by strengthening existing system and not establishing any parallel system [10]. However, the choice of distribution strategy was based on agreement between local government (DHO) and UNICFF without involving Puskesmas staff 37 cadres in the decision making process. Since a number of programs are attached to Posyandu of which needs good involvement of cadres and other respective personnel, this kind of agreement needs to be revisited. Poor recording of MNP logistic resulted in overstock of MNP at Posyandu as a result of no specific job description and areas of responsibility of nutrition staff responsible for MNP distribution observed in this study, would be a consequence of one sided agreement like this kind.

Although Posyandu had good accessibility for cadre and mother since most of Posyandu located in the center of sub-village, however, not all of mother/caregiver acknowledged about MNP distribution. This might occur since most mother/caregiver obtained the information through announcement from the mosque which might not cover all member of the community. Besides, there were about $22.9 \%$ mothers/caregivers did not routinely visit Posyandu in the last six months, mostly due to busy doing household tasks and working. These showed that Posyandu alone as channel of MNP distribution would have not been enough. Various channel of MNP distribution might be needed to distribute MNP to the community, such example exist in Nigeria where three different strategies of delivery mechanism of vitamin A supplementation program implemented flexibly: fixed post, advanced post and mobile strategy, responding to the uneven geographical condition to have a 
successful program of vitamin A distribution [15].

This study observed that sweeping activity, similarly as mobile strategy in Nigeria, was not seriously implemented. MNP was delivered from Puskesmas to Posyandu on the day of distribution and to be given to mother/caregiver who attended Posyandu. If they were not shown up, cadre was supposed to conduct sweeping activity; however, not all Posyandu confirmed the expected sweeping activity it was rarely implemented. Sometimes cadres asked the neighbors to pass MNP to mother/caregiver who didn't visit Posyandu. Similar practice occurred in vitamin A distribution program in several areas of Indonesia [16]. This problem should be addressed accordingly: could it be a lack of cadre's commitment, unavailability of incentive for sweeping activity or cadre's heavy workload.

The inconsistency of MNP delivery was due to unavailability of SOP or guideline and improper program planning, a result of a top-down program and unavailability of local planning ever made by Puskesmas. Furthermore, the socialization of the program was conducted one month prior to first distribution which considered as a very short time.

The irregularity of MNP distribution during the last six months was due to miss-communication between interns of UNICEF. Although the request made by DHO already included MNP needs for one year, however, UNICEF was only able to provide half of MNP needs sufficient for less than six months. Since this program required huge number of MNP, proper planning and management of logistic are needed. DHO agreed to receive this shortage of stock as DHO experienced some difficulties to distribute MNP due to low acceptance of MNP resulting in abundant of leftovers up to Posyandu level.

There was no requesting system especially for MNP ever made by Posyandu up to DHO. No survey conducted especially to get the list of MNP targeted children. DHO only used list of underfive children based on Puskesmas report on growth monitoring program which might be not updated regularly. DHO requested MNP needs based on the report and projection data. This practice might have given inaccurate assessment of MNP needs, hence inaccurate supply from UNICEF as it found that most Posyandu experienced over-stock of MNP. Furthermore, last request of DHO to UNICEF was made more than one year prior to MNP distribution schedule. This could contribute to even more inaccuracy data of MNP needs. DHO and Puskesmas should strengthen their task of getting an apropriate data on population of underfive children.

UNICEF set the deadline for request at least six months in advanced to give them enough time to provide the MNP stocks. This practice was better than the vitamin A supplementation program in West Kalimantan province, where there was no deadline of vitamin A capsules request to $\mathrm{MOH}$ and usually the request was submitted one month before delivery. However, unlike in this MNP program, the mechanism of vitamin A request from Posyandu up to DHO was available [16].

Besides inaccuracy assessment of MNP needs, the fact that some of mother/caregiver did not want to take MNP might also lead to abundant leftovers of MNP. Unavailability records of MNP logistic available at DHO up to Posyandu would also have contributed to over-stock of MNP. Poor record of MNP logistic allowed poor information on quantities of MNP at different distribution levels. Puskesmas staff continuously delivered MNP without monitoring the leftovers at Posyandu. Those might be the causes of most Posyandu experienced over-stock of MNP.

The availability of MNP storing system observed in this study was very poor. Most Posyandu in this study kept MNP stocks in no specific room with high 
humidity, and possible contamination of cockroach and mouse, as it recognized in many circumstances in which MNP storage is possible in those improper condition. If it happened, the products should have been produced suitable with their best shelf life under prevailing condition, adapt packaging and advice customers and users on the expected shelf life [17]. Therefore, supplier of MNP should put this condition into consideration.

Puskesmas staff only delivered MNP stock to Posyandu monthly without performing any other tasks such as monitoring and supervision of MNP distribution. Therefore, cadre rarely received feedback on MNP program due to no specific report of Puskesmas supervision. Similar condition of supervision from DHO to Puskesmas also occurred: no records of supervision available as well as at DHO. Based on interview with Puskemas staff, low acceptance of MNP was already known since first semester of MNP distribution. Puskesmas already sent this information to DHO but there was no feedback given to overcome the problem. More than one year after, DHO and UNICEF conducted survey to find out more about the low acceptance of MNP. Afterwards, several facilitators were selected to assist MNP distribution on every village. Unfortunately, this effort was initiated only several months before the last MNP distributed.

This study observed lack and ineffective supervision with regards to feed back given to overcome the existing problem. Nutrition staff of Puskesmas claimed that their workload were too much since most Puskesmas programs attached to nutrition section, whereby only 2-3 nutrition staff available in each Puskesmas, considering one Puskesmas should supervised 25 Posyandu. This fact resulted in limited and ineffective supervision to Posyandu. Similarly, some cadres also mentioned about their extra responsibilities of running this additional MNP program in
Posyandu and claimed no incentives since the previous year. A study on public funding in health at district level in Indonesia after decentralization observed that allocation for health center only less than a quarter of public funds for health [18]. As UNICEF intention to have the MNP program to be embedded to the local existing health system, the local health authority should have been able to address this problem. Propose funding allocation for distribution of MNP as well as additional staffs of nutrition section at Puskemas are necessary for the success of MNP program.

Training on MNP program was very limited. Since the initiation of the program, there were only two trainings for cadres, with no refreshers training in between and only half of cadre's coordinator attended the second training. Review among several countries in South Asia revealed that continuous training was found to be an essential prerequisite for an effective community health workers program [19]. Limited qualified training for cadres and low participation of cadres to attend training might be the causes of poor knowledge of cadres regarding MNP program especially the importance of accurate data on targeted children. Poor knowledge would also probably due to incontinuity and irregularity of training. Continuous and qualified training would improve knowledge, motivation and skill of cadres in delivering program for community [20].

This study also revealed that there were lack of community participation especially participation by head of subvillages. Their contribution to the program was mostly by only informing Posyandu day which actually at the same time scheduled for MNP distribution, despite efforts to socialize the program started by inviting sub-village heads and implementing regulation for them to became cadre in their Posyandu. Posyandu has a concept of community ownership aiming for the welfare of the community. 
Therefore, coordination among stakeholders should be an integrated efforts amongst all of them, with the sub-village head as the focal person [21].

Report of MNP distribution at Posyandu was using custom format from DHO and integrated with vitamin $\mathrm{A}$ and deworming tablet report. Cadre reported only list of children received MNP with no information about number of MNP sachets received by each child. Inconsistent data on number of children received MNP from Posyandu up to DHO was also observed. These conditions might have given impact on inaccuracy of coverage calculation.

This study revealed that the coverage of MNP distribution was low $(<50 \%)$. However, report from DHO stated that coverage of MNP distribution was $\geq 90 \%$. This discrepancy might be due to inaccuracy and inconsistency of data on targeted children at $\mathrm{DHO}$, since cadres only reported those who attended Posyandu, excluding other targeted children who did not attend Posyandu. Report from Posyandu were used by Puskesmas and furthermore to DHO as the source of their report. Consequently, over reporting would have been produced. It was also found that Puskesmas had reported high coverage of MNP distribution and no leftovers. However, by observation, it was found that there were still several boxes of MNP leftovers in Puskesmas and abundant stocks at Posyandu.

The low coverage was a result of low sweeping activity, poor recording and reporting system, ineffective supervision, lack of qualified training for cadres, unavailability of request mechanism low level, financial support for operational of MNP distribution and lack of community participation. All of essential components of MNP distribution system were mostly deficient. Since all of them were interrelated to each other, any deficiency of those components might give influence to others; hence, coverage of MNP distribution as an outcome of the system was low. This was in agreement with findings of vitamin A distribution study in three provinces of Indonesia, in which improper functioning on its several essential components influencing the low coverage as well [16]. This low coverage might also influenced by the low acceptance of MNP itself as most mothers/caregivers mentioned their child dislike MNP due to organoleptic changes on food sprinkled MNP and some cadres also confirmed this fact, hence, mother/caregiver refused to receive MNP. This fact might be the consequences of improper practice of MNP use. However, this study were not exploring on practice of MNP use among mother/caregiver.

Effective program should be based on sound information about the setting and consideration to create demand among different stakeholders, namely politicians, health care providers and parents, to enhance program uptake and at the end for the betterment of child nutrition [22]. The need of proper local program planning is highly required to achieve the goal of the program. This study also shows how important it is to highly recognize a study on program delivery to the success of a new health program to be scaled-up.

It is obvious, that at least in Praya Tengah sub-district, MNP delivery was not working properly, meaning that MNP did not reach targeted underfive children.

\section{CONCLUSIONS AND RECCOMENDATIONS}

Most of all essential components of MNP distribution system were mostly deficient. Deficiencies were due to poor planning and management, no requesting mechanism from Posyandu to DHO, poor record system and resources at Posyandu and Puskesmas, no financial support for MNP distribution, ineffective supervisions, inadequate training for cadre and lack of support from community leader. Since all of the sub-systems were interrelated to each other, any deficiency might give 
effect to others, and consequently, coverage of MNP distribution was low.

Recommendations to be addressed are provision comprehensive study regarding local health system especially capacity of resources before running a future MNP program, provision of proper local program planning and management of MNP program accustomed to the available health care delivery service capacity, provision of complete SOP and guidelines for MNP distribution prior to program implementation, requirement to develop mutual agreements among stakeholders of a sharing planned MNP distribution activities, a study to recognize other possible channel for MNP distribution and increasing awareness of study in program delivery is highly recommended.

\section{REFERENCES}

1. Zlotkin, S., et al., Treatment of anemia with microencapsulated ferrous fumarate plus ascorbic acid supplied as sprinkles to complementary (weaning) foods. Am J Clin Nutr, 2001. 74(6): p. 791-795.

2. Zlotkin, S., et al., Home-Fortification with Iron and Zinc Sprinkles or Iron Sprinkles Alone Successfully Treats Anemia in Infants and Young Children. J. Nutr., 2003. 133(4): p. 1075-1080.

3. Giovannini, M., et al., Double-blind, placebo-controlled trial comparing effects of supplementation with two different combinations of micronutrients delivered as sprinkles on growth, anemia, and iron deficiency in cambodian infants. $\mathrm{J}$ Pediatr Gastroenterol Nutr, 2006. 42(3): p. 306-12.

4. Sharieff, W., et al., Micronutrients (including zinc) reduce diarrhoea in children: the Pakistan Sprinkles Diarrhoea Study. Arch Dis Child, 2006. 91(7): p. 573-9.
5. Hyder, Z., et al., Effect of daily versus once weekly home fortification with sprinkles on haematological and iron status among young children in rural Bangladesh. Food Nutr Bull, 2007. 28(2): p. 156-64.

6. Hirve, S., et al., Low dose 'Sprinkles'-an innovative approach to treat iron deficiency anemia in infants and young children. Indian Pediatr, 2007. 44(2): p. 91-100.

7. Menon, P., et al., Micronutrient Sprinkles Reduce Anemia among 9- to 24-Mo-Old Children When Delivered through an Integrated Health and Nutrition Program in Rural Haiti. J. Nutr., 2007. 137(4): p. 1023-1030.

8. UNICEF, Workshop Report on Scaling up the use of multiple micronutrient powders to improve the quality of complementary foods for young children in Asia. 2009, UNICEF: Bangkok.

9. Bryce, J., et al., Reducing child mortality: can public health deliver? Lancet, 2003. 362(9378): p. 159-64.

10. UNICEF, Final Draft-Community Health Systems Strengthening Program Design in Lombok Tengah, NTB Province 2007.

11. Lwanga, S.K. and S. Lemeshow, Sample size determination in health studies. 1991, Geneva: WHO.

12. HKI, Final Report of the Food for Progress, Vitalita Sprinkles Effectiveness Program (SEP) for the period May 2003 - July 2006. 2006.

13. Jahari, A.B., et al., The effectiveness of multiple micronutrients fortificant $(M M F)$ on growth and hemoglobinconcentration among underfives of poor families in North Jakarta. 2008, Center for Research and Development in Nutrition and Food, MOH RI.

14. UNICEF and CHR-UI, Baseline study of health and nutrition services and community participation in Central Lombok, West NusaTenggara Province 2007. 2007. 
15. Aguayo, V.M., et al., Maintaining high vitamin $A$ supplementation coverage in children: lessons from Niger. Food Nutr Bull, 2005. 26(1): p. 26-31.

16. Pangaribuan, R., et al., Survey of vitamin A coverage in three selected low-high performance areas of Indonesia. 2007, SEAMEOTROPMED and UNICEF: Jakarta.

17. de Pee, S., et al., Quality criteria for micronutrient powder products: report of a meeting organized by the World Food Programme and Sprinkles Global Health Initiative. Food Nutr Bull, 2008. 29(3): p. 232-41.

18. Heywood, P. and N. Harahap, Public funding of health at the district level in Indonesia after decentralization sources, flows and contradictions. Health Research Policy and Systems, 2009. 7(1): p. 5.

19. UNICEF, What Works for Children in South Asia: Community Health Workers. 2004, UNICEF.
20. Bhattacharyya, K., et al., Community Health Worker Incentives and Disincentives: How They Affect Motivation, Retention, and Sustainability. 2001, Arlington, Virginia: The Basic Support for Institutionalizing Child Survival Project (BASICS II) for the United States Agency for International Development.

21. Indonesia, M.o.H., General Guidelines for Management of Posyandu. 2006, Jakarta: Ministry of Health of Indonesia.

22. WHO and UNICEF, Strengthening action to improve feeding of infants and young children 6-23 months of age in nutrition and child health programmes. 2008, WHO: Switzerland. 